\title{
Perinatal and Neonatal Outcomes of Triplet Gestations Based on Chorionicity
}

\author{
Maureen Downing, DO ${ }^{1}$ Suela Sulo, $\mathrm{PhD}^{2} \quad$ Barbara V. Parilla, MD ${ }^{1}$ \\ ${ }^{1}$ Division of Maternal-Fetal Medicine, Department of Obstetrics and \\ Gynecology, Advocate Lutheran General Hospital, Park Ridge, Illinois \\ 2 The James R. and Helen D. Russell Institute for Research \& \\ Address for correspondence Barbara V. Parilla, MD, 1875 W \\ Dempster St., Suite 325, Park Ridge, IL 60068 \\ (e-mail: Barbara.Parilla@advocatehealth.com).
}

Innovation, Advocate Lutheran General Hospital, Park Ridge, Illinois

Am J Perinatol Rep 2017;7:e59-e63.

\begin{abstract}
Keywords

- monochorionic triplets

- triplet outcomes based on chorionicity

- dichorionic triplets

- diamniotic

- monochorionic twin pair in triplet gestation

- triplet gestation outcomes

Objective To compare perinatal and neonatal outcomes of dichorionic (DC) and monochorionic (MC) with trichorionic (TC) triplet gestations.

Methods A retrospective cohort study of DC $+M C$ versus TC triplet gestations delivered at a tertiary care hospital from 2009 to 2015. The results include 42 sets of triplets (TC, $n=26$; DC + MC, $n=16$ ). Maternal demographics and pregnancy data were compared. Neonatal outcomes were assessed using composite morbidity and mortality.

Results Maternal baseline characteristics including age, mode of conception, race, parity, body mass index, and previous preterm delivery were statistically comparable. Comparison of prenatal management and complications yielded no significant differences in terms of presence of shortened cervix, cerclage placement, use of tocolytics, intrauterine growth restriction, premature rupture of membranes, pregnancy-induced hypertension, or gestational diabetes. However, evaluation of composite morbidity and mortality (RDS, IVH, NEC, IUGR, and death) illustrated that all infants born from DC + MC triplet gestations suffered some morbidity or mortality compared with TC pregnancies $(p<0.01)$.

Conclusion $\mathrm{DC}+\mathrm{MC}$ triplet gestations are at an increased risk of neonatal morbidity and mortality compared with TC triplet gestations.
\end{abstract}

The incidence of multiple gestations has risen significantly over several decades. This is primarily due to the increased use of fertility drugs for ovulation induction, superovulation, and assisted reproductive technologies (ARTs), such as in vitro fertilization (IVF). In 1960, before the commercial availability of drugs for the treatment of infertility, there were approximately 4.3 million births in the United States, with 1,244 triplets and higher-order multiples. In 2011, the total number of births was slightly lower (3.9 million), but there were 5,417 triplets and higher-order multiples. ${ }^{1}$ Approximately $20 \%$ of higher-order multiple births are naturally conceived, 39 to $67 \%$ are related to ovulation induction/ superovulation, and 13 to $44 \%$ are associated with ART.

received

December 20, 2016 accepted after revision January 9, 2017
DOI http://dx.doi.org/ $10.1055 / \mathrm{s}-0037-1599124$. ISSN 2157-6998.
Multiple gestations are at significantly increased risk of fetal, neonatal, and maternal complications, as well as complete pregnancy loss, when compared with singleton pregnancies. In a recent review, the risk of delivery $<32$ weeks of gestation for singleton, twin, triplet, and quadruplet pregnancies was $2,8,26$, and $>95 \%$, respectively. ${ }^{2}$

Most IVF centers in the United States look to balance success along with limiting higher-order multiples. ${ }^{3}$ However, even with the transfer of two embryos, there appears to be an increasing number of triplet gestations with a monochorionic (MC) twin pair. ${ }^{4}$ This occurs when one of the transferred embryos splits into a twin pair that shares a placenta. The monochorionic twin pairs suffer additional
Copyright @ 2017 by Thieme Medical Publishers, Inc., 333 Seventh Avenue, New York, NY 10001, USA. Tel: +1(212) 584-4662.
License terms

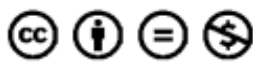


risks of growth discordance and twin-twin transfusion syndrome (TTTS), as compared with dichorionic (DC) twin gestations. ${ }^{5}$ This translates into even earlier preterm delivery rates and increased morbidity, mortality, and long-term sequelae of prematurity. 6,7

Studies evaluating triplet pregnancy outcomes in relation to chorionicity have been few and may not reflect contemporary antenatal and neonatal care. ${ }^{8-10}$ We aimed to compare perinatal and neonatal outcomes in triplet gestations based on placental chorionicity in a contemporary cohort. We hypothesized that triplets containing a DC or MC placenta continue to have increased morbidity and mortality compared with a trichorionic (TC) triplet gestation.

\section{Methods}

This was a retrospective cohort study of triplet gestations delivered at $\geq 20$ weeks at a tertiary care hospital from 2009 to 2015. Data were abstracted through the hospital and outpatient office electronic medical records. A total of 42 sets of triplets were found to be eligible for analysis, of which 26 were TC, 14 DC, and 2 MC. The DC and MC gestations were combined into one group ( $D C+\mathrm{MC}, n=16$ ) for the comparisons. All gestations were triamniotic. This study was approved by the Advocate Institutional Review Board and a waiver of consent was obtained.

The primary outcome was composite neonatal morbidity and mortality, including respiratory distress syndrome (RDS), intraventricular hemorrhage (IVH), necrotizing enterocolitis (NEC), < 10th percentile birth weight, and death.

We relied on a convenience sample size of eligible neonates who met the study eligibility criteria. Descriptive statistics for continuous variables are reported as mean \pm standard deviation (SD), while count and percent are reported for all categorical variables. Comparative analysis between the TC versus DC $+\mathrm{MC}$ groups were compared using independent Student $t$-tests or Wilcoxon Rank sum tests for the continuous variables, and Pearson chi-square or Fisher's exact test for the categorical variables as applicable. All analyses were performed using SPSS for Windows, version 22.0 (SPSS Inc., Chicago, IL). A two-tailed $p$ level of 0.05 was considered statistically significant in all analyses.

\section{Results}

Maternal baseline characteristics were comparable as outlined in - Table 1. Except for race and body mass index (BMI), with more patients in the TC group being of non-Hispanic/ white or Asian/Pacific Islander descent $(p=0.04)$ and having higher BMIs ( $p=0.02$ ), no other differences were noted.

All patients were managed by the maternal-fetal medicine service with a standardized protocol for fetal surveillance based on chorionicity. There were no significant differences in pregnancy complications (-Table 2 ), including the presence of a shortened cervix, cerclage placement, use of tocolytics, premature rupture of membranes, pregnancyinduced hypertension, gestational diabetes, or TTTS. Significantly more patients in the combined DC + MC group received vaginal progesterone ( 43.8 vs. $11.5 \%, p=0.03$ ). An increased risk of intrauterine growth restriction (IUGR) was noted in the DC + MC group (25 vs. 3.8\%); however, the difference was not statistically significant given the small number of patients $(p=0.06)$.

No statistically significant differences were noted for the recorded pregnancy outcomes between the groups (all $p$ values $>0.05$; - Table 3 ). The risk of preterm delivery was higher between 28 and 32 weeks in the DC + MC group (37.5 vs. $11.5 \%)$, but not statistically significant $(p=0.06)$. TTTS ( $n=2,12.5 \%$ ) was noted only in the DC + MC group.

Most neonatal outcomes were comparable between the groups (-Table 4). However, a significant decrease in birth weight was noted in the $\mathrm{DC}+\mathrm{MC}$ group, especially for

Table 1 Maternal baseline characteristics

\begin{tabular}{|c|c|c|c|c|}
\hline Variable & $\begin{array}{l}\text { Total } \\
n=42\end{array}$ & $\begin{array}{l}\text { Trichorionic } \\
\text { Triamniotic } \\
n=26\end{array}$ & $\begin{array}{l}\text { Dichorionic }+ \text { monochorionic } \\
\text { Triamniotic } \\
n=16\end{array}$ & $p$ Value \\
\hline Maternal age $(y)$, mean ( \pm SD) & $33.4( \pm 4.43)$ & $33.5( \pm 4.7)$ & $33.3( \pm 4.1)$ & 0.85 \\
\hline \multicolumn{5}{|l|}{ Mode of conception, $n(\%)$} \\
\hline $\begin{array}{l}\text { Spontaneous } \\
\text { Ovulation induction } \\
\text { Assisted (IVF, IUI) }\end{array}$ & $\begin{array}{l}5(11.9) \\
2(4.8) \\
35(83.3)\end{array}$ & $\begin{array}{l}4(15.4) \\
2(7.7) \\
20(76.9)\end{array}$ & $\begin{array}{l}1(6.3) \\
0 \\
15(93.8)\end{array}$ & $\begin{array}{l}0.63 \\
0.52 \\
0.22\end{array}$ \\
\hline \multicolumn{5}{|l|}{ Race, $n(\%)$} \\
\hline $\begin{array}{l}\text { Non-Hispanic/white } \\
\text { Black } \\
\text { Hispanic } \\
\text { Asian/Pacific Islander }\end{array}$ & $\begin{array}{l}35(83.3) \\
2(4.8) \\
1(2.4) \\
4(9.5)\end{array}$ & $\begin{array}{l}24(92.3) \\
2(7.7) \\
0 \\
0\end{array}$ & $\begin{array}{l}11(68.8) \\
0 \\
1(6.3) \\
4(25.0)\end{array}$ & $\begin{array}{l}0.04^{\mathrm{a}} \\
0.52 \\
0.38 \\
0.02^{\mathrm{a}}\end{array}$ \\
\hline Nulliparous, $n(\%)$ & $19(45.2)$ & $11(42.3)$ & $8(50.0)$ & 0.63 \\
\hline Body mass index $\left(\mathrm{kg} / \mathrm{m}^{2}\right)$, mean $( \pm \mathrm{SD})$ & $32.6( \pm 7.2)$ & $34.3( \pm 8.1)$ & $29.69( \pm 4.5)$ & $0.02^{\mathrm{a}}$ \\
\hline Previous preterm delivery, $n(\%)$ & $3(7.1)$ & $2(7.7)$ & $1(6.3)$ & 1.00 \\
\hline
\end{tabular}

Abbreviations: IUI, intrauterine insemination; IVF, in vitro fertilization; SD, standard deviation.

${ }^{a} p<0.05$. 
Table 2 Prenatal management and complications

\begin{tabular}{|c|c|c|c|c|}
\hline Variable & $\begin{array}{l}\text { Total } \\
n=42\end{array}$ & $\begin{array}{l}\text { Trichorionic } \\
\text { Triamniotic } \\
n=26\end{array}$ & $\begin{array}{l}\text { Dichorionic }+ \text { monochorionic } \\
\text { Triamniotic } \\
n=16\end{array}$ & $p$ Value \\
\hline Short cervix, $n(\%)$ & $3(7.1)$ & $2(7.7)$ & $1(6.3)$ & 1.00 \\
\hline GA diagnosis, mean ( \pm SD) & $21.8( \pm 1.9)$ & $21.3( \pm 2.1)$ & $23.0( \pm 0.1)$ & 0.56 \\
\hline Cerclage, $n(\%)$ & $6(14.3)$ & $4(15.4)$ & $2(12.5)$ & 1.00 \\
\hline Tocolytic therapy, $n$ (\%) & $24(57.1)$ & $13(50.0)$ & $11(68.8)$ & 0.23 \\
\hline Vaginal progesterone, $n(\%)$ & $10(23.8)$ & $3(11.5)$ & $7(43.8)$ & $0.03^{\mathrm{a}}$ \\
\hline \multicolumn{5}{|l|}{ Corticosteroids, $n(\%)$} \\
\hline $\begin{array}{l}1 \text { course } \\
2 \text { courses }\end{array}$ & $\begin{array}{l}19(45.2) \\
11(26.2)\end{array}$ & $\begin{array}{l}11(42.3) \\
5(19.2)\end{array}$ & $\begin{array}{l}8(50.0) \\
6(37.5)\end{array}$ & $\begin{array}{l}0.75 \\
0.28\end{array}$ \\
\hline IUGR, $n(\%)$ & $5(11.9)$ & $1(3.8)$ & $4(25.0)$ & 0.06 \\
\hline PROM, $n(\%)$ & $13(31.0)$ & $10(38.5)$ & $3(18.8)$ & 0.30 \\
\hline $\mathrm{PIH}, n(\%)$ & $13(31.0)$ & $9(34.6)$ & $4(25.0)$ & 0.73 \\
\hline Gestational DM, $n(\%)$ & $4(9.5)$ & $3(11.5)$ & $1(6.3)$ & 1.00 \\
\hline TTTS, $n(\%)$ & $2(4.8)$ & 0 & $2(12.5)$ & 0.14 \\
\hline
\end{tabular}

Abbreviations: DM, diabetes mellitus; GA, gestational age; IUGR, intrauterine growth retardation; PIH, prolactin inhibitory hormone; PROM, premature rupture of membranes; SD, standard deviation; TTTS, twin-twin transfusion syndrome.

${ }^{\mathrm{a} p}<0.05$.

neonates $\mathrm{B}$ and $\mathrm{C}(p=0.03$ and 0.01 , respectively). Similar results were noted for neonates $B$ and $C$ when they were categorized into $<10$ th percentile birth weight $(p=0.04)$. Also, neonates $C$ in the $D C+M C$ group were statistically more likely to have low APGAR (American Pediatric Gross Assessment Record) scores compared with the neonates in the TC group ( 8.9 vs. $8.4, p=0.05$ ). Both neonatal deaths were noted in triplet $C$.

There was a significant difference in the composite morbidity and mortality between the groups, and all DC $+\mathrm{MC}$ gestations suffered some morbidity. Two neonatal deaths were from complications of prematurity (RDS, IVH, NEC). One of the pregnancies was complicated by TTTS in an MC gestation with delivery at 26 weeks and neonatal death at day 9 of life, whereas the other was a TC gestation complicated by spontaneous preterm delivery at 25 weeks and neonatal death on day 2 of life. The other case of TTTS in our cohort delivered at 29 weeks. Finally, the overall survival to discharge home in this contemporary cohort of triplets was 39/42 (92.9\%).

\section{Discussion}

This study results suggest that all DC and MC gestations in this cohort suffered some morbidity or mortality. Our results are consistent with prior studies showing that a triplet gestation that is fully MC or has an MC twin pair is at higher risk of complications than a triplet gestation that is $\mathrm{TC}^{4,5}$ Because of

Table 3 Pregnancy outcomes

\begin{tabular}{|c|c|c|c|c|}
\hline Variable & $\begin{array}{l}\text { Total } \\
n=42\end{array}$ & $\begin{array}{l}\text { Trichorionic } \\
\text { Triamniotic } \\
n=26\end{array}$ & $\begin{array}{l}\text { Dichorionic }+ \text { monochorionic } \\
\text { Triamniotic } \\
n=16\end{array}$ & $p$ Value \\
\hline \multicolumn{5}{|l|}{ GA at delivery, $n(\%)$} \\
\hline $\begin{array}{l}32-37 w k \\
28-32 w k \\
<28 w k\end{array}$ & $\begin{array}{l}28(66.7) \\
9(21.4) \\
5(11.9)\end{array}$ & $\begin{array}{l}20(76.9) \\
3(11.5) \\
3(11.5)\end{array}$ & $\begin{array}{l}8(50.0) \\
6(37.5) \\
2(12.5)\end{array}$ & $\begin{array}{l}0.10 \\
0.06 \\
1.00\end{array}$ \\
\hline \multicolumn{5}{|l|}{ Delivery, $n$ (\%) } \\
\hline $\begin{array}{l}\text { Spontaneous labor } \\
\text { Induction } \\
\text { Medical indication }\end{array}$ & $\begin{array}{l}24(57.1) \\
7(16.7) \\
11(26.2)\end{array}$ & $\begin{array}{l}17(65.4) \\
5(19.2) \\
4(15.4)\end{array}$ & $\begin{array}{l}7(43.8) \\
2(12.5) \\
7(43.8)\end{array}$ & $\begin{array}{l}0.21 \\
0.69 \\
0.09\end{array}$ \\
\hline $\mathrm{PPH}, n(\%)$ & $6(14.3)$ & $5(19.2)$ & $1(6.3)$ & 0.38 \\
\hline Blood transfusion, $n(\%)$ & $7(16.7)$ & 7 (26.9) & 0 & NA \\
\hline
\end{tabular}

Abbreviations: GA, gestational age; NA, not applicable; PPH, postpartum hemorrhage. 
62 Triplet Pregnancy Outcomes by chorionicity Downing et al.

Table 4 Neonatal outcomes

\begin{tabular}{|c|c|c|c|c|}
\hline Variable & $\begin{array}{l}\text { Total } \\
n=42\end{array}$ & $\begin{array}{l}\text { Trichorionic } \\
\text { Triamniotic } \\
n=26\end{array}$ & $\begin{array}{l}\text { Dichorionic }+ \\
\text { monochorionic } \\
\text { Triamniotic } \\
n=16\end{array}$ & $p$ Value \\
\hline \multicolumn{5}{|c|}{$\begin{array}{l}\text { Low APGAR }(<7) \text { at } 5 \text { minute, mean } \\
( \pm \mathrm{SD})\end{array}$} \\
\hline $\begin{array}{l}\text { Neonate A } \\
\text { Neonate B } \\
\text { Neonate C }\end{array}$ & $\begin{array}{l}8.7( \pm 0.6) \\
8.8( \pm 0.5) \\
8.7( \pm 0.6)\end{array}$ & $\begin{array}{l}8.8( \pm 0.4) \\
8.9( \pm 0.3) \\
8.9( \pm 0.3)\end{array}$ & $\begin{array}{l}8.4( \pm 0.8) \\
8.6( \pm 0.7) \\
8.4( \pm 0.7)\end{array}$ & $\begin{array}{l}0.09 \\
0.07 \\
0.05^{\mathrm{a}}\end{array}$ \\
\hline Congenital malformations, $n$ (\%) & $3(7.1)$ & $2(7.7)$ & $1(6.3)$ & 1.00 \\
\hline \multicolumn{5}{|l|}{ NICU admission, $n(\%)$} \\
\hline $\begin{array}{l}\text { Neonate A } \\
\text { Neonate B } \\
\text { Neonate C }\end{array}$ & $\begin{array}{l}7(16.7) \\
9(21.4) \\
8(19.0)\end{array}$ & $\begin{array}{l}5(19.2) \\
4(15.4) \\
3(11.5)\end{array}$ & $\begin{array}{l}2(12.5) \\
5(31.3) \\
5(31.3)\end{array}$ & $\begin{array}{l}0.40 \\
0.72 \\
0.45\end{array}$ \\
\hline $\operatorname{LOS}(d)$, mean $( \pm S D)$ & $9.64( \pm 9.9)$ & $8.29( \pm 7.8)$ & $12( \pm 12.3)$ & 0.28 \\
\hline$>30 \%$ discordance, $n(\%)$ & $5(11.9)$ & $3(11.5)$ & $2(12.5)$ & 1.00 \\
\hline \multicolumn{5}{|l|}{ RDS, $n(\%)$} \\
\hline $\begin{array}{l}\text { Neonate A } \\
\text { Neonate B } \\
\text { Neonate C }\end{array}$ & $\begin{array}{l}24(57.1) \\
27(64.3) \\
25(59.5)\end{array}$ & $\begin{array}{l}13(50.0) \\
18(69.2) \\
15(57.7)\end{array}$ & $\begin{array}{l}11(68.8) \\
9(56.3) \\
10(62.5)\end{array}$ & $\begin{array}{l}0.20 \\
1.00 \\
0.74\end{array}$ \\
\hline \multicolumn{5}{|l|}{ IVH grades 3 and 4, $n(\%)$} \\
\hline $\begin{array}{l}\text { Neonate A } \\
\text { Neonate B } \\
\text { Neonate C }\end{array}$ & $\begin{array}{l}0 \\
0 \\
2(4.8)\end{array}$ & $\begin{array}{l}0 \\
0 \\
1(3.8)\end{array}$ & $\begin{array}{l}0 \\
0 \\
1(6.3)\end{array}$ & $\begin{array}{l}\text { NA } \\
\text { NA } \\
1.00\end{array}$ \\
\hline \multicolumn{5}{|l|}{ NEC, $n(\%)$} \\
\hline $\begin{array}{l}\text { Neonate A } \\
\text { Neonate B } \\
\text { Neonate C }\end{array}$ & $\begin{array}{l}3(7.1) \\
0 \\
1(2.4)\end{array}$ & $\begin{array}{l}1(3.8) \\
0 \\
0\end{array}$ & $\begin{array}{l}2(12.5) \\
0 \\
1(6.3)\end{array}$ & $\begin{array}{l}0.54 \\
\text { NA } \\
0.37\end{array}$ \\
\hline \multicolumn{5}{|l|}{ Death, $n(\%)$} \\
\hline $\begin{array}{l}\text { Neonate A } \\
\text { Neonate B } \\
\text { Neonate C }\end{array}$ & $\begin{array}{l}0 \\
0 \\
3(7.1)\end{array}$ & $\begin{array}{l}0 \\
0 \\
1(3.8)\end{array}$ & $\begin{array}{l}0 \\
0 \\
2(12.5)\end{array}$ & $\begin{array}{l}\text { NA } \\
\text { NA } \\
0.54\end{array}$ \\
\hline \multicolumn{5}{|l|}{$<$ 10th percentile birth weight, $n$ (\%) } \\
\hline $\begin{array}{l}\text { Neonate A } \\
\text { Neonate B } \\
\text { Neonate C }\end{array}$ & $\begin{array}{l}10(23.8) \\
5(11.9) \\
5(11.9)\end{array}$ & $\begin{array}{l}6(23.1) \\
1(3.8) \\
1(3.8)\end{array}$ & $\begin{array}{l}4(25.0) \\
4(25.0) \\
4(25.0)\end{array}$ & $\begin{array}{l}0.72 \\
0.04^{\mathrm{a}} \\
0.04^{\mathrm{a}}\end{array}$ \\
\hline \multicolumn{5}{|l|}{ Birth weight $(g)$, mean $( \pm S D)$} \\
\hline $\begin{array}{l}\text { Neonate A } \\
\text { Neonate B } \\
\text { Neonate C }\end{array}$ & $\begin{array}{l}1,644.6 \\
( \pm 557.7) \\
1,715.1 \\
( \pm 503.4) \\
1,694.3 \\
( \pm 520.9)\end{array}$ & $\begin{array}{l}1,717.89 \\
( \pm 579.4) \\
1,844.2 \\
( \pm 508.6) \\
1,846.9 \\
( \pm 483.6)\end{array}$ & $\begin{array}{l}1,508.5 \\
( \pm 506.8) \\
1,475.4 \\
( \pm 409.4) \\
1,446.3 \\
( \pm 496.2)\end{array}$ & $\begin{array}{l}0.26 \\
0.03^{\mathrm{a}} \\
0.01^{\mathrm{a}}\end{array}$ \\
\hline $\begin{array}{l}\text { Composite morbidity (M) and } \\
\text { mortality (M), } n(\%)^{\mathrm{b}}\end{array}$ & $105(83.3)$ & $57(73.1)$ & $48(100)$ & $<0.01^{\mathrm{c}}$ \\
\hline
\end{tabular}

Abbreviations: APGAR, American Pediatric Gross Assessment Record; IVH, intraventricular hemorrhage; LOS, length of stay; NA, not applicable; NEC, necrotizing enterocolitis; NICU, neonatal intensive care unit; RDS, respiratory distress syndrome; SD, standard deviation.

${ }^{a} p \leq 0.05$.

${ }^{\mathrm{b} C o m p o s i t e ~ M \& M}=\mathrm{RDS}, \mathrm{IVH}, \mathrm{NEC},<10$ th percentile birth weight, death.

${ }^{c} p<0.01$.

the increased rate of complications associated with MC gestations, determination of chorionicity by late first-trimester or early second-trimester ultrasound is imperative for counseling and management with multifetal gestation.
One of the most important factors in the increased risk of neonatal morbidity and mortality associated with triplet gestations is the development of TTTS. The only two cases of TTTS in our study were in DC + MC gestations, and the rate 
of $12.5 \%$ observed is similar to that noted in MC twins. Interestingly, a recent study noted a lower than expected rate of TTTS in DC triplets $(3 / 51,5.8 \%) .{ }^{11}$ The authors stated that it was unclear whether DC triplet pregnancies are inherently at less risk for developing TTTS as compared with MC twins. They went on to speculate that the presence of the third gestational sac may act as a buffer, reducing pressure on the chorionic plate when hydramnios is present, thereby decreasing the risk of developing TTTS, similar to the mechanisms postulated by which amnioreduction may improve TTTS.

The recent decrease in the rate of multiple gestations is the result of a reduction in the number of embryos transferred with each cycle of IVF, and an increase in the number of multiple pregnancy reduction procedures being performed. The ARTs that have the most significant effect on the increase in multifetal gestations are IVF and ovarian hyperstimulation with gonadotropins. Even with the transfer of two embryos, there appears to be an increasing number of triplet gestations with an MC twin pair. ${ }^{4}$ Further research is needed to elucidate the risk factors and ARTs that increase the risk of monozygotic twinning.

Limitations of this study include the retrospective nature and relatively small sample size. More specifically, because of its retrospective nature, the study is limited in terms of data availability and accuracy, while the potential for statistical errors such as a type 2 error ("false negative") due to the relatively small sample size is possible. Although future studies utilizing larger groups of prospectively enrolled patients are needed, it is important to note that this study represents a real-world experience of a large referral and tertiary care center in the northwest suburbs of Illinois. Although this study was underpowered to show a difference in mortality and individual morbidities between the groups, all DC and MC gestations suffered some morbidity or mortality.

It is important to note that neonatal morbidity and mortality in nonanomalous fetuses are due primarily to prematurity issues, and this is particularly evident in multiple gestations. Twenty-five percent of all DC or MC triplet gestations in our cohort had IUGR. These pregnancies are frequently delivered early for fetal indications. The management of growth disorders in triplets needs to be evaluated further to determine whether earlier delivery is needed, or if close observation is feasible to decrease iatrogenic prematurity.

Financial Disclosure

The authors have no conflicts of interest to report.

Presented as a poster at the Annual Meeting of the American College of Obstetricians and Gynecologists, May 14-17, 2016, Washington, DC, United States.

\section{References}

1 Martin JA, Hamilton BE, Osterman MJ. Three decades of twin births in the United States, 1980-2009. NCHS Data Brief 2012;$(80): 1-8$

2 American College of Obstetricians and Gynecologists; Society for Maternal-Fetal Medicine. ACOG Practice Bulletin No. 144: Multifetal gestations: twin, triplet, and higher-order multifetal pregnancies. Obstet Gynecol 2014;123(05):1118-1132

3 Practice Committee of American Society for Reproductive Medicine. Multiple gestation associated with infertility therapy: an American Society for Reproductive Medicine Practice Committee opinion. Fertil Steril 2012;97(04):825-834

4 Parilla BV, Goldman B, Jasulaitis S, Sulo S, Beltsos A. Risk factors associated with dichorionic triplet gestations. Open J Obstet Gynecol 2015;5(13):740-745

5 Ortibus E, Lopriore E, Deprest J, et al. The pregnancy and long-term neurodevelopmental outcome of monochorionic diamniotic twin gestations: a multicenter prospective cohort study from the first trimester onward.Am J Obstet Gynecol2009;200(05):494.e1-494.e8

6 Kawaguchi H, Ishii K, Yamamoto R, Hayashi S, Mitsuda N; Perinatal Research Network Group in Japan. Perinatal death of triplet pregnancies by chorionicity. Am J Obstet Gynecol 2013;209(01): 36.e1-36.e7

7 Bajoria R, Ward SB, Adegbite AL. Comparative study of perinatal outcome of dichorionic and trichorionic iatrogenic triplets. Am J Obstet Gynecol 2006;194(02):415-424

8 Chasen ST, Al-Kouatly HB, Ballabh P, Skupski DW, Chervenak FA. Outcomes of dichorionic triplet pregnancies. Am J Obstet Gynecol 2002;186(04):765-767

9 Geipel A, Berg C, Katalinic A, et al. Prenatal diagnosis and obstetric outcomes in triplet pregnancies in relation to chorionicity. BJOG 2005;112(05):554-558

10 Spencer JV, Ingardia CJ, Nold CJ, Borgida AF, Herson VC, Egan JFX. Perinatal and neonatal outcomes of triplet gestations based on placental chorionicity. Am J Perinatol 2009;26(08):587-590

11 Lopes Perdigao J, Straub H, Zhou Y, Gonzalez A, Ismail M, Ouyang DW. Perinatal and obstetric outcomes of dichorionic vs trichorionic triplet pregnancies. Am J Obstet Gynecol 2016;214(05):659. e1-659.e5 